\title{
Estudo morfológico do sistema respiratório de quati (Nasua nasua)
}

\author{
Vanessa Cristina de Oliveira ${ }^{1 *}$ \\ Aline Fernanda Souza ${ }^{1}$ \\ Amilton César dos Santos ${ }^{1}$ \\ Bruno Machado Bertassoli ${ }^{1}$ \\ Ricardo Alexandre Rosa ${ }^{2}$ \\ Ana Flávia de Carvalho ${ }^{2}$ \\ João Flavio Panattoni Martins ${ }^{2}$ \\ Celina Almeida Furlanetto Mançanares ${ }^{1}$ \\ ${ }^{1}$ Faculdade de Zootecnia e Engenharia de Alimentos \\ PPG em Anatomia dos Animais Domésticos e Silvestres \\ Av. Duque de 2 Caxias Norte, 225, CEP 13635-900, Pirassununga - SP, Brasil \\ ${ }^{2}$ Centro Universitário da Fundação de Ensino Octávio Bastos, São João da Boa Vista - SP, Brasil \\ *Autor para correspondência \\ van.cristina.oliveira@hotmail.com
}

Submetido em 22/03/2011 Aceito para publicação em 03/11/2011

\section{Resumo}

O objetivo deste trabalho foi descrever a morfologia macroscópica e microscopia de luz dos órgãos respiratórios do quati (Nasua nasua). Utilizou-se cinco animais provenientes do Criatório Científico CECRIMPAS (UNIfeob), os quais foram eutanasiados e fixados em solução de formaldeído a $10 \%$ para dissecação, análise e mensuração. Para microscopia de luz, os fragmentos dos órgãos respiratórios, foram processados conforme técnicas rotineiras para histologia e corados por Hematoxilina, Eosina e Azul de Toluidina. O nariz do quati está localizado em plano nasal, formato pontiagudo e voltado para cima, possui a concha etmoidal,/nasal dorsal e nasal ventral separadas pelos meatos: nasal dorsal e ventral. A laringe /possui as quatro cartilagens: aritenóide, cricoíde, epiglote e tireóide e a traqueia contém 34 anéis traqueais separados pelo ligamento traqueal, sendo internamente revestida pelo tecido epitelial pseudoestratificado ciliado. Os pulmões estão subdivididos em lobos por fissuras interlobares, o pulmão direito é dividido em quatro lobos e o esquerdo em dois, sendo este menor que o direito. Microscópicamente os brônquios primários, secundários e terciários possuem a mesma constituição de revestimento interno da traqueia. Concluímos que o aparelho respiratório do quati se assemelha aos achados descritos na literatura para os carnívoros domésticos.

Palavras-chave: Morfologia, Quati, Respiratório 


\section{Abstract}

Morphological study of the respiratory system of the brown-nosed coati (Nasua nasua). The goal of this study was to describe, macroscopically and with light microscopy, the respiratory organs of the brown-nosed coati (Nasua nasua). Five animals were euthanized, fixed in 10\% formaldehyde solution and stored for dissection. The respiratory tracts of the coati were examined, measured and photographed. For the light microscopy study, fragments were collected from the respiratory organs, processed using standard techniques for histology and stained with HE and toluidine blue. The nose of the coati is pointed and turned upward. Internally it has ethmoidal, dorsal nasal and ventral nasal conchae that are separated by the dorsal and ventral nasal meatuses. The larynx has four cartilaginous structures: arytenoid, cricoid, epiglottis and thyroid. The trachea contains 34 tracheal rings and tracheal ligaments that are covered with ciliated pseudostratified epithelial tissue. The lungs are divided into lobes by interlobular fissures. The right lung is divided into four lobes and is larger than the left lung, whereas the left lung has only two lobes. Microscopically, the primary, secondary and tertiary bronchi have epithelial tissue that is similar to the trachea. We conclude that the respiratory tract of the brown-nosed coati resembles the respiratory tracts described for domestic carnivores.

Key words: Coati, Morphology, Respiratory

\section{Introdução}

O quati é um animal que pertence ao Filo Chordata, à Classe Mammalia, à Ordem Carnívora e à Família Procyonidae (ZELLER, 1999).

Segundo Orr (1986) estes animais são classificados como plantígrados podendo realizar movimentos em diferentes direções, podem chegar a ter $30,5 \mathrm{~cm}$ de altura, seu comprimento varia entre $43-66 \mathrm{~cm}$, mais $22-69 \mathrm{~cm}$ de cauda e podem atingir até $11 \mathrm{~kg}$.

As fêmeas de quatis são matriarcas e vivem com seus filhotes em bandos de até 30 indivíduos, já os machos, quando se tornam adultos, ficam isolados e só se aproximam do grupo na época de acasalamento (BEISIEGEL, 2001; TEIXEIRA; AMBRÓSIO, 2007).

O quati possui o nariz em forma de trombeta que o auxilia durante a escavação, por toda à parte em busca de alimentos. Apresenta a cauda longa, anelada e intercalada de cores claras e escuras sendo esta estrutura utilizada para manter o equilíbrio. Alimentam-se de minhocas, insetos e frutas apreciando também ovos, legumes, lagartos e pequenos roedores (RUSSEL, 1996).

O sistema respiratório compreende os pulmões e um sistema de tubos que comunicam o parênquima pulmonar com o meio exterior. Este sistema é dividido por uma porção condutora, formada pelo nariz, fossas nasais, nasofaringe, laringe, traqueia, brônquios e bronquíolos, e uma porção respiratória formada pelos bronquíolos respiratórios, ductos alveolares, sacos alveolares e alvéolos pulmonares (JUNQUEIRA; CARNEIRO, 1999).

Os estudos a respeito de animais silvestres vêm crescendo dia a dia, e com este interesse necessitamos de mais informações sobre sua anatomia, fisiologia, comportamento e outros aspectos importante para sua sobrevivência (REGINATO; MELO, 2004).

Assim devido à escassez de literatura sobre a morfologia do sistema respiratório de quati (Nasua nasua), nos propomos a estudar e analisar estas estruturas, através de analises macroscópicas e microscopia de luz, para que possamos, através de dados obtidos nestas pesquisas, adquirir melhores conhecimentos básicos deste sistema e compará-lo com outras espécies.

\section{Material e Métodos}

Para realização deste estudo, respeitou-se todos os parâmetros Internacionais da bioética e bem estar animal, conforme preconiza a Comissão de Ética da Faculdade de Medicina Veterinária de São João da Boa Vista - UNIFEOB.

Foram utilizados cinco animais de ambos os sexos, sem idade definida, provenientes do Criatório Científico (CECRIMPAS) UNIfeob autorizado pelo IBAMA com o Processo: no 02027.003731/04-76. Estes animais foram eutanasiados com thelazol ${ }^{\circledR}$ 
$0,20 \mathrm{mg} / \mathrm{kg}$ e injetados com $10 \mathrm{~mL}$ de cloreto de potássio intravenoso e posteriormente fixados em solução aquosa de formoldeído a $10 \%$. Tanto a artéria carótida quanto a veia jugular foram perfundidas com látex Neoprene 650, corado com pigmento vermelho e azul respectivamente.

Para análise macroscópica do sistema respiratório do quati, realizou-se, com bisturi, duas incisões nos ramos laterais da mandíbula, sendo rebatidos o esôfago e a traqueia entre as fáscias musculares cervicais, até a entrada da cavidade torácica. Com o auxílio de um costótomo foi feita a desarticulação das costelas na junção costocondral, expondo completamente o tórax para a retirada dos órgãos respiratórios. Estas estruturas foram identificadas, dissecadas, mensuradas e fotografadas.

Para análise microscópica os órgãos do sistema respiratório foram fragmentados e colocados em solução fixadora de paraformaldeído 4\% em PBS pH 7,4 a 0,1M. Após a fixação, o material foi desidratado em uma série de etanóis em concentrações crescentes (de 70 a 100\%) e diafanizado em xilol, seguido de inclusão em parafina Histosec $^{\circledR}$ (BEHMER et al., 1976; TOLOSA et al., 2003). Os blocos e suas diferentes porções foram cortados em um micrótomo LEICA ${ }^{\circledR}$, modelo 2165, com espessura média de $5 \mu \mathrm{m}$. Os cortes foram corados seguindo as técnicas de Hematoxilina e Azul de Toluidina e após as colorações, as lâminas foram montadas com lamínulas, utilizando-se Entelan ${ }^{\circledR}$ (Merck).

O material foi analisado, mapeado e fotografado através de um Fotomicroscópio Nikon Eclipse E-400 e Zeiss Axioplan MC8DX, descrevendo-se microscopicamente todas as regiões distintas do sistema respiratório desta espécie.

As informações pertinentes à morfologia foram descritas conforme o International Comitee on Veterinary Gross Anatomical Nomenclature (2005).

\section{Resultados e Discussão}

No quati as características são semelhantes aos animais domésticos descrito por Hare (1975) e Dyce et al. (2004), o nariz encontra-se incorporado dentro do esqueleto da face, este localizado em plano nasal com o formato pontiagudo e voltado para cima. As narinas são separadas pelo septo nasal (Figura 1A), e dentro destas encontram-se as fossas nasais, ou cavidades nasais, que se comunicam com uma cavidade revestida por muco, chamada de seios paranasais. Os seios paranasais são considerados como divertículos da cavidade nasal, em que se adentram aos ossos do crânio, nossos achados revelam que o quati apresenta seio paranasal dividido em cranial e caudal (Figura 2 A).

As analises microscópicas revelaram que o tecido de revestimento do nariz do quati é do tipo epitelial pavimentoso estratificado queratinizado, com glândulas sebáceas ou holócrinas, ácinos mistos (Figura 1B), folículos pilosos (Figura 1C), regiões com fibroblastos e ácinos serosos (Figura 1D), assim como descrito por Gartner e Hiatt (1999) nos animais domésticos.

Nos animais domésticos descritos por König e Liebich (2004), as conchas nasais penetram na cavidade nasal, se projetam da parede lateral e quase atingem o septo nasal, sendo este igualmente observado no quati, em que apresentou três conchas nasais: a concha etmoidal, a concha nasal dorsal e a concha nasal ventral (Figura 2B). A concha etmoidal constitui a massa lateral do osso etmóide, a concha nasal dorsal é mais curta e larga e a concha nasal ventral é mais alongada e estreita, diferente dos resultados encontrados nos cães por König e Liebich (2004) que é ao inverso, sendo a concha nasal dorsal alongada e estreita e a concha nasal ventral curta e larga.

A concha nasal dorsal e a concha nasal ventral são separadas por meatos, os meatos encontrados foram: meato nasal dorsal, meato nasal médio e meato nasal ventral (Figura 2B) igual aos achados de König e Liebich (2004) nos animais domésticos.

As conchas nasais são estruturas ósseas revestidas por mucosa, possuem epitélio colunar pseudoestratificado ciliado com células caliciformes, sendo apoiado em tecido conjuntivo frouxo e ricamente vascularizado concordando com o descrito por Millas et al., (2009) em humanos (Figura 3).

No quati a faringe é subdividida em três regiões: nasofaringe, orofaringe e laringofaringe igualmente os achados de Gartner e Hiatt (1999) nos animais domésticos. 
FIGURA 1: Fotografia e Fotomicrografia do nariz do quati. Em A observar o nariz com formato de trombeta, narinas (N) e septo nasal (Sn); B elucida epitélio pavimentoso estratificado queratinizado (seta grossa), ácinos mistos (seta fina); em C notamos o folículo piloso (seta cheia) e glândula sebácea (seta fina) e em D observamos os ácinos serosos (seta). H.E Barra $200 \mu \mathrm{m}$ e $20 \mu \mathrm{m}$.
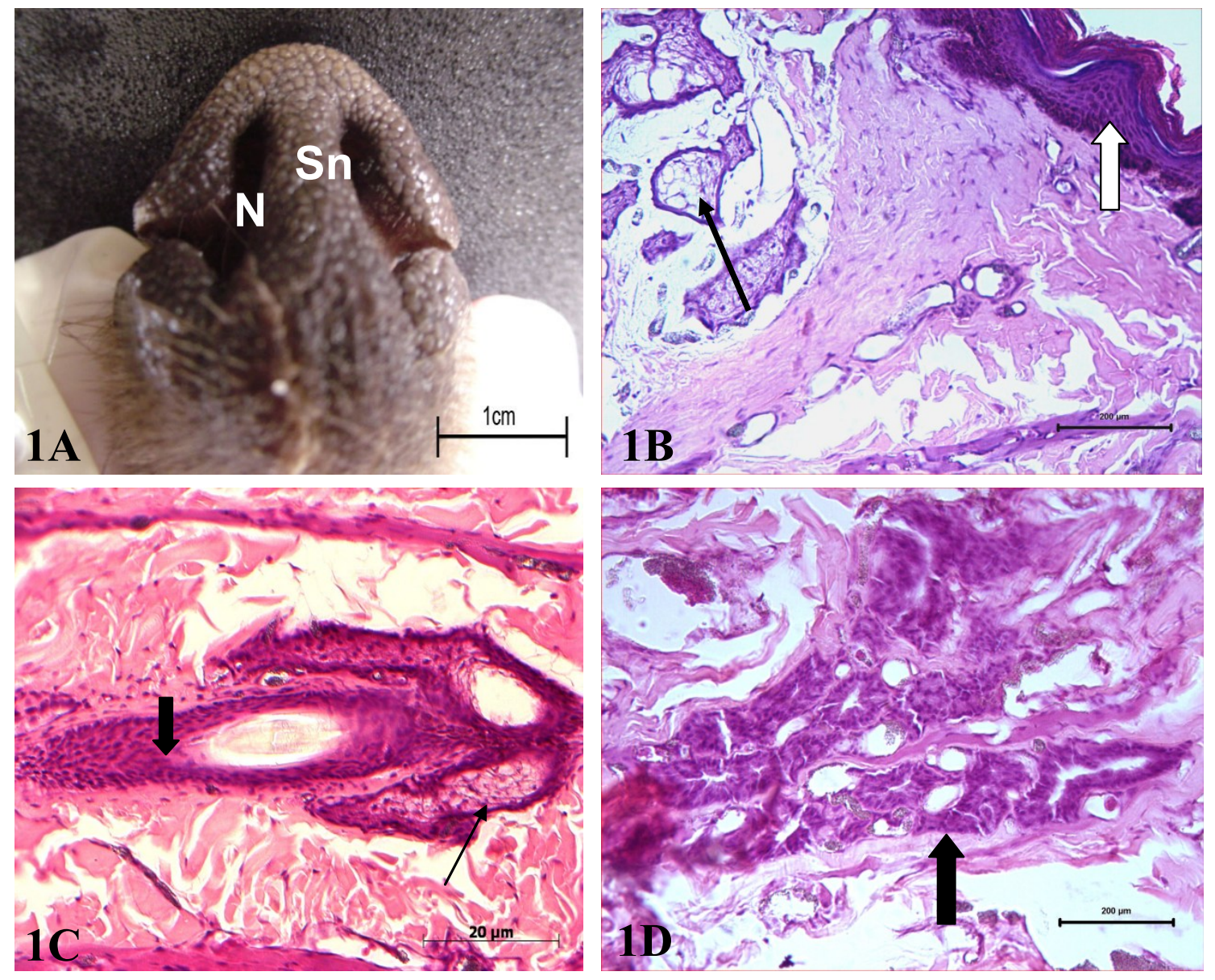

FIGURA 2: Fotografias do seio paranasal e das conchas nasais do quati. Observar em A o seio paranasal cranial (PCr) e o seio paranasal caudal (PCa) e em B notar concha nasal dorsal $(\mathrm{Cd})$, concha nasal ventral $(\mathrm{Cv})$, concha etmoidal (Ce), meato nasal dorsal (seta branca) e meato nasal médio (seta fina) e meato nasal ventral (seta preta).
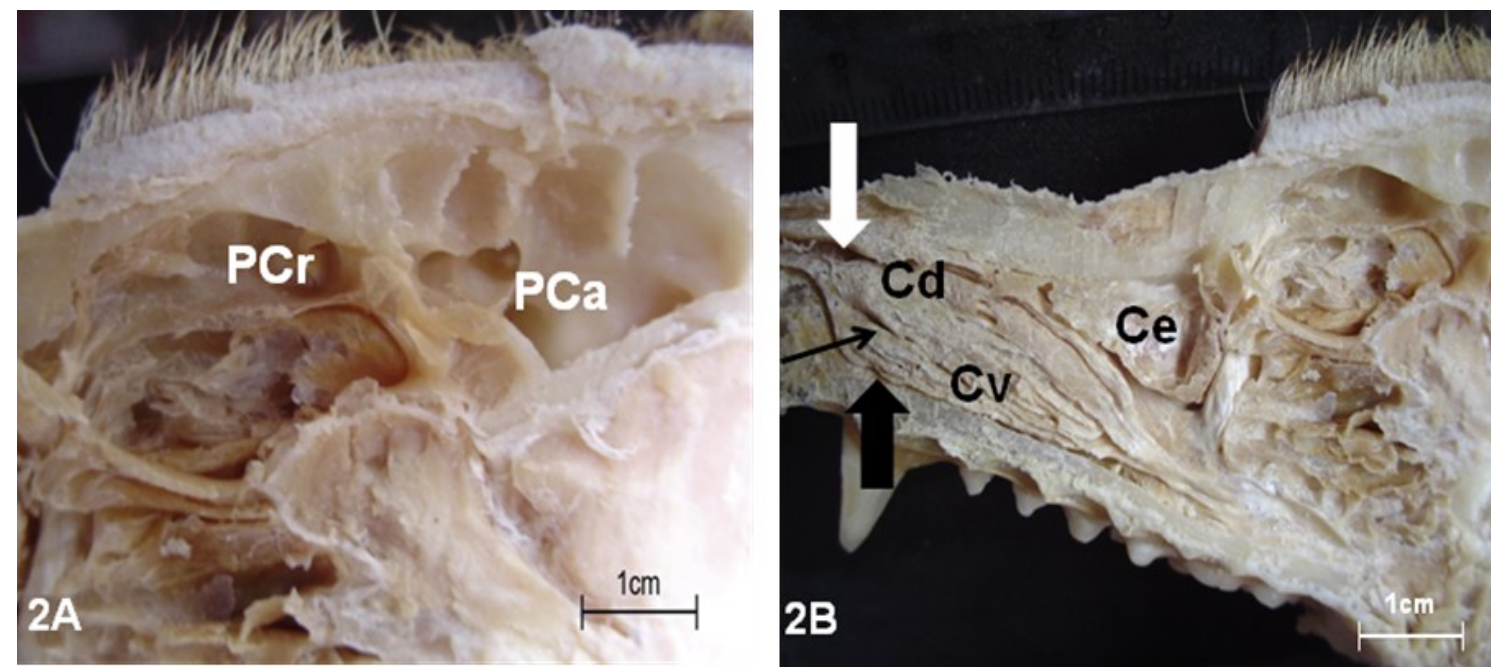
FIGURA 3: Fotomicrografia da concha nasal do quati, notar células caliciformes (seta fina) e epitélio pseudoestratificado ciliado (seta cheia). Barra $20 \mu \mathrm{m}$. H.E

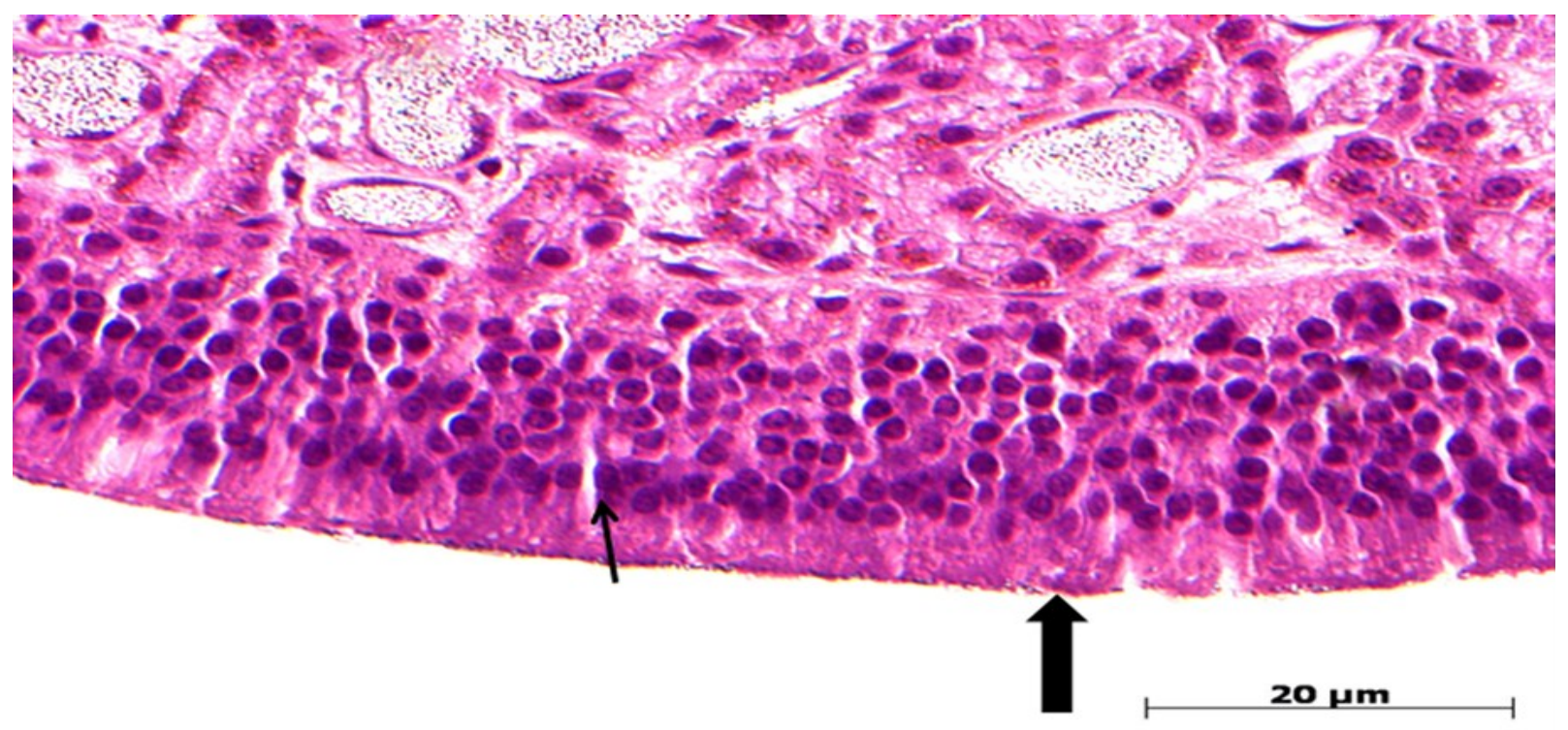

A laringe do quati, a qual apresenta vestíbulo seguido pelas pregas vocais é composta por quatro cartilagens: cricóide, tireóide e aritenóide com o processo corniculado e a epiglote.

Concordando com Dyce et al. (2004) nos animais domésticos, a cartilagem aritenóide tem uma forma irregular, descrita como piramidal, e possui o processo corniculado que se prolonga dorsomedialmente, formando a margem caudal da entrada da laringe (Figura 4 A).

A cartilagem cricóide apresenta um anel em forma de sinete (Figura 4A) e consiste em um selo dorsal expandido (lâmina) e um arco ventral mais estreito. A parte dorsal apresenta uma crista mediana, e possui duas facetas para as cartilagens aritenóideas (Figura 4B), concordando com Dyce et al. (2004) nos animais domésticos.

A cartilagem epiglote é predominantemente rostral, consiste em uma pequena haste e uma grande lâmina em forma de folha (Figura 4C), em repouso a cartilagem epiglótica inclina-se dorsorrostralmente atrás do palato mole, concordando com os relatos de Dyce et al. (2004) nos animais domésticos.

A cartilagem tireóide é a maior das cartilagens laríngeas situa-se dorsalmente a cartilagem cricóide, consiste em duas laminas laterais que se encontram ventralmente, onde se fundem em grau variável, formando a maior parte do assoalho da laringe (Figura 4D).
No que tange os aspectos microscópicos, a cartilagem aritenoíde é formada por cartilagem hialina com grupos isógenos de condrócitos, pericôndrio, músculo estriado esquelético, ácinos mistos, mucosos e serosos, assemelhando-se ao modelo suíno descrito por Carrijo (2007). O epitélio de revestimento observado foi o epitélio estratificado pavimentoso queratinizado na parte ventral e sobre a parte dorsal são cobertas por epitélio pavimentoso estratificado não queratinizado (Figura 5A), igualmente encontrado nos suínos segundo Pereira (2006).

A cartilagem cricóide é revestida por epitélio pavimentoso estratificado não queratinizado na região ventral, enquanto que, a região dorsal é revestida pelo epitélio pavimentoso estratificado queratinizado. Foram observados ácinos mucosos e músculo estriado esquelético. É composta por cartilagem hialina que formam grupos isógenos de condrócitos e por um pericôndrio bem desenvolvido (Figura 5B), assim com descrito por Pereira (2006) em suínos.

A cartilagem epiglote é formada por cartilagem elástica, onde se formam as fibras elásticas, observou-se ácinos mistos e o epitélio de revestimento encontrado foi do tipo pavimentoso estratificado não queratinizado (Figura 5C e 5D).

A cartilagem tireóide é composta por músculo liso transversal e músculo liso longitudinal (Figura 5E), possui 
FIGURA 4: Fotografia das cartilagens da laringe do quati. Notar em A cartilagem aritenóide (Ca), com o processo corniculado $(\mathrm{Pc})$ e cartilagem cricóide (Cc) com o arco da cricóide (seta); em B a crista da cricóide (seta) e a lâmina (L); C cartilagem epiglote $(\mathrm{Ce})$ com formato de folha; em $\mathrm{D}$ a cartilagem tireóide $(\mathrm{Ct})$. Técnica de dissecação
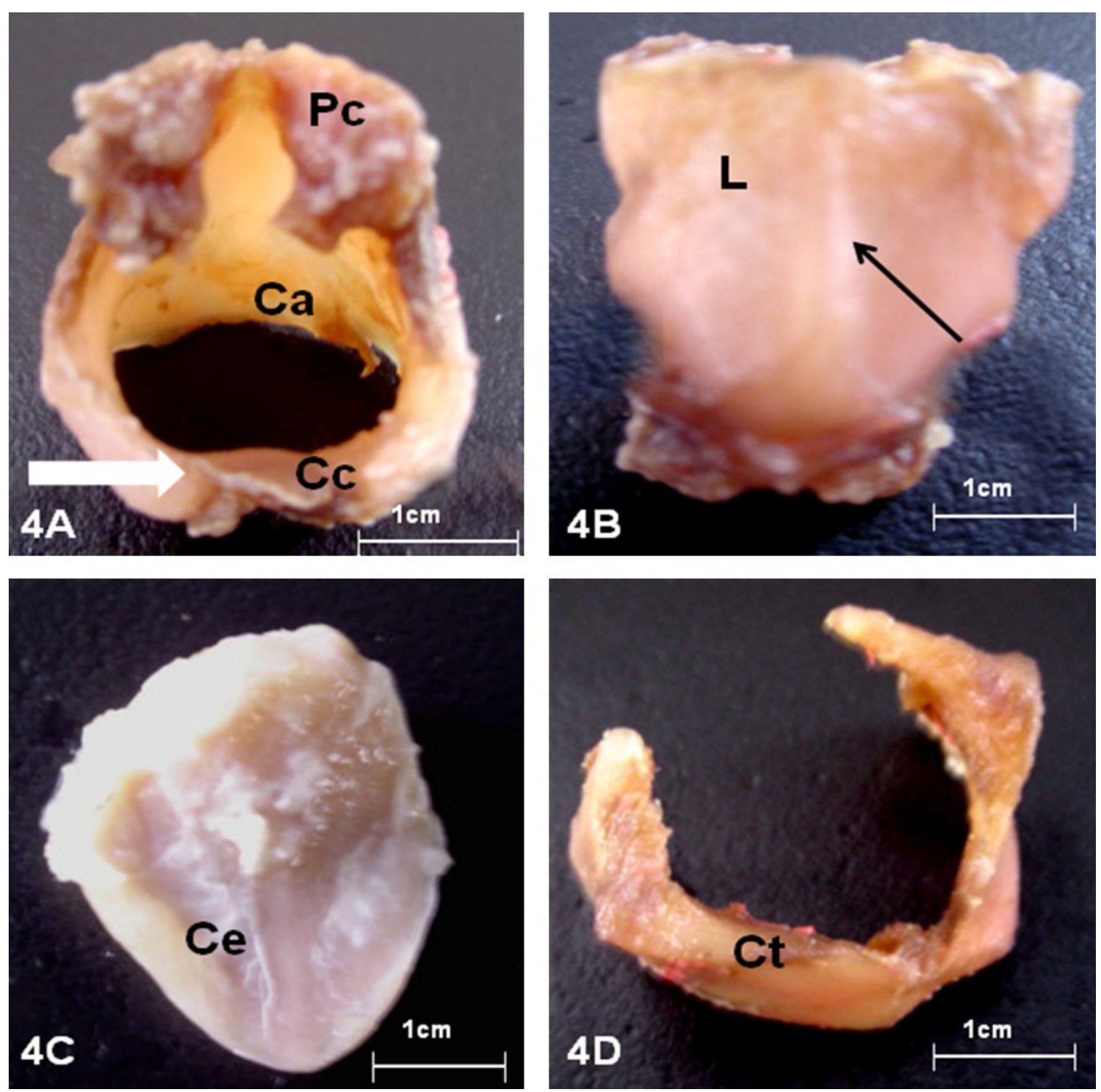
FIGURA 5: Fotomicrografias das cartilagens da laringe do quati (Nasua nasua). Em A observar a cartilagem aritenóide, com músculo liso (M), cartilagem hialina com grupos isógenos de condrócitos (seta); B, cartilagem cricóide, com cartilagem hialina, pericôndrio (seta fina), ácino mucoso (seta cheia) e músculo estriado esquelético (M); em C e D destacamos a cartilagem epiglote, com fibras elásticas (C),epitélio pavimentoso não queratinizado (seta), grupos isógenos de condrócitos (E) e ácinos mistos (seta),em E elucidamos a direção nas fibras musculares da cartilagem tireóide com músculo liso transversalmente (seta cheia) e músculo liso longitudinalmente (seta fina) e em F a cartilagem tireóide mostrando cartilagem hialina, grupos isógenos de condrócitos (seta) e músculo liso (M). H.E.Barra: $20 \mu \mathrm{m}$ e $200 \mu \mathrm{m}$.
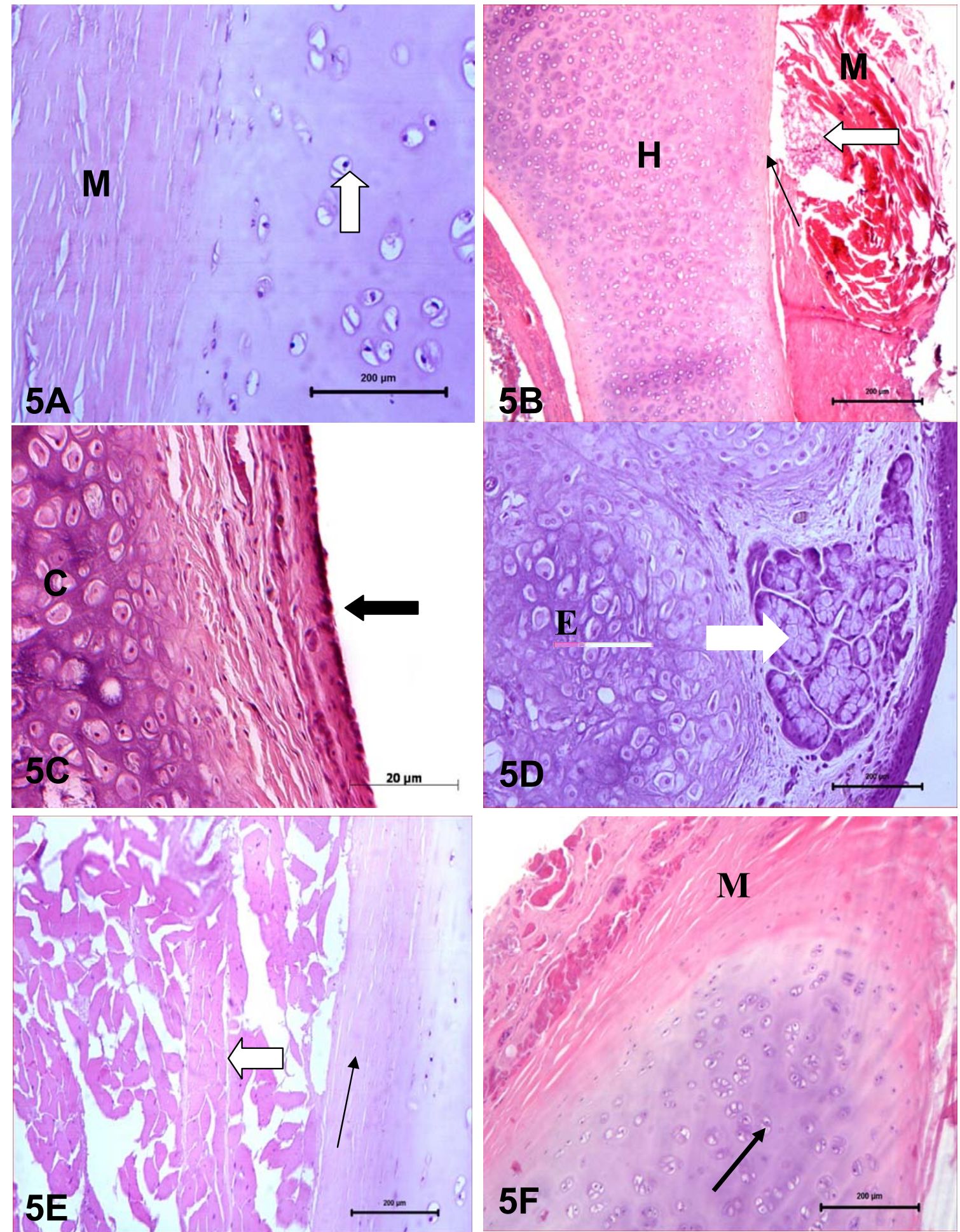
cartilagem hialina com grupos isógenos de condrócitos, sendo recoberta por músculo liso (Figura $5 \mathrm{~F}$ ) de acordo com Gartner e Hiatt (1999) nos animais domésticos.

A traqueia é um tubo cartilaginoso flexível e membranoso, situa-se caudalmente a laringe, através do espaço visceral do pescoço, adentra o mediastino na entrada torácica e continua até sua bifurcação terminal sobre o coração. Lateralmente à traqueia, acompanha o nervo laringorecorrente, concordando com os relatos de Dyce et al. (2004) nos animais domésticos.
Segundo Hare (1975) e Dyce et al. (2004), nos animais domésticos os números de anéis traqueais são diversos, nos mamíferos variando de 29 a 60 (29 a 36 em suínos, 38 a 46 em carnívoros e 48 a 60 em herbívoros). Nos gansos domésticos, citados por Santos et al. (2008), foram encontrados 144 anéis traqueais e no quati em média 34 anéis traqueais, podendo se enquadrar próximo ao modelo suíno (Figura 6A). Em relação ao tamanho foi notado do primeiro anel traqueal até a carina traqueal, $11,5 \mathrm{~cm}$ em média.

FIGURA 6: Fotografias e Fotomicrografias da traqueia do quati. Notar em A a traqueia (T) "in situ" com formato tubular e em B a união dos anéis traqueais (At) e ligamentos traqueais (seta). Em C e D, observar o epitélio pseudoestratificado ciliado (seta preta grossa), ácinos serosos (seta branca), músculo liso (M) e cartilagem hialina com grupos isógenos de condrócitos $(\mathrm{H})$; pericôndrio (seta fina), músculo liso transversal (Mt) e músculo liso longitudinal (ML). H.E.Barra: $20 \mu \mathrm{m}$ e $200 \mu \mathrm{m}$.
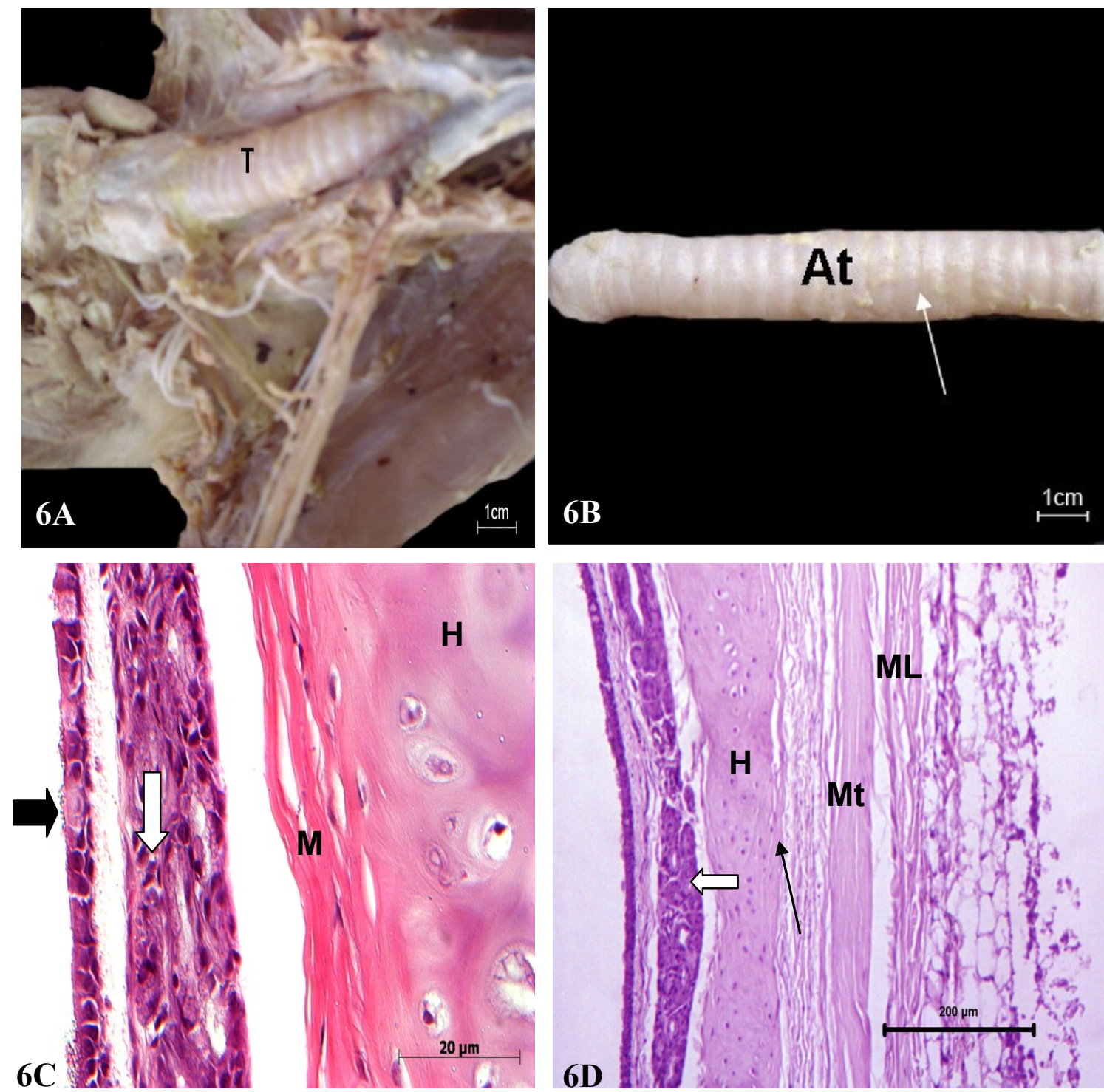
Concordando com Gartner e Hiatt (1999) em humanos, no quati a traqueia é constituida por anéis cartilaginosos incompletos, sendo unidos por ligamentos traqueais (Figura 6B) e histologicamente é revestida pelo epitélio respiratório, contendo células ciliadas e mucosas. Seu epitélio é do tipo pseudoestratificado ciliado com células caliciformes e próximo da superfície epitelial encontram-se células epitéliais cilíndricas, que possuem cílios móveis ou microvilos (Figura 6C). Dentro do epitélio, em uma camada média, localizam-se os núcleos das células caliciformes, enquanto os núcleos adjacentes à membrana basal pertencem às células cilíndricas que não chegam à superfície epitelial.

Igual observado no ratão do banhado, por Resende et al. (2007), a traqueia possui o epitélio pseudoestratificado ciliado, com celulas caliciformes, ácino seroso, músculo liso, grupos isógenos de condrócitos, pericôndrio (Figura 6C), músculo liso longitudinal e músculo liso transversal.

Nos quatis, assim como nos demais mamíferos, descritos por Cunninghan (2004), os pulmões são cobertos pela pleura visceral e as costelas pela pleura parietal. Apresentam-se divididos em direito e esquerdo e se encontram invaginados dentro de um saco pleural, na cavidade torácica, onde se apresentavam livres, exceto nas raízes que estavam presas ao mediastino pelo ligamento pulmonar, conforme descrição de Trindade et al., (2003) nos bovinos azebuados.

Dyce et al. (2004) descrevem que os pulmões estão subdivididos em lobos por profundas fissuras interlobares. No quati o pulmão direito é divido em quatro lobos e é maior que o esquerdo, sendo este constituído por somente dois lobos. O lobo direito é dividido em lobo cranial, médio, caudal e um acessório, e o lobo esquerdo é divido em lobo cranial e caudal (Figura 7 A). Foram observadas a mesma quantidade de lobos na cutia (PENNO et al., 2005) e na capivara (CITRÂNGULO et al., 2001), diferentemente dos resultados encontrados por Greene (1995) nos ratos, que apresentavam quatro lobos no pulmão direito e apenas um lobo no pulmão esquerdo; nas marmotas (NAKAKUKI, 1994), o pulmão direito possui quatro lobos e o esquerdo três sendo estes unidos formando um único lobo; nas pacas (BORGES et al., 2002; REDHER,
2005) e nos fetos de búfalos (OLIVEIRA et al., 1999), os lobos encontrados foram quatro (cranial, médio, caudal e lobo acessório) no pulmão direito, e no pulmão esquerdo: lobo cranial, dividido em segmentos cranial e caudal e o lobo caudal.

Cooper e Schiller (1975) notaram que na cobaia o pulmão direito é maior que o esquerdo, sendo que no quati, resultados semelhantes foram observados, pois o pulmão esquerdo do ápice até a base apresentou extensão média de $11,4 \mathrm{~cm}$ e o pulmão direito de $12,6 \mathrm{~cm}$.

No quati, em média o pulmão esquerdo mediu $11,4 \mathrm{~cm}$ de comprimento, de seu ápice cranial até a sua base caudal; sua largura máxima (encontrada no lobo caudal) foi de $5,8 \mathrm{~cm}$ de sua borda medial até a sua borda costal e a espessura máxima (encontrado na borda medial do lobo caudal) foi de $2,5 \mathrm{~cm}$ e apresentou dois lobos: cranial e caudal.

Amedida do lobo cranial foi de $7 \mathrm{~cm}$ de comprimento, do seu ápice até a sua base e largura de $4,8 \mathrm{~cm}$ de sua borda medial até a sua borda costal e sua espessura máxima foi encontrada na borda medial $1,5 \mathrm{~cm}$.

O lobo caudal mediu 7,3cm de seu ápice cranial até sua base caudal e 5,6cm de largura da borda medial até sua borda costal e sua espessura máxima foi encontrada na borda medial e foi de $2,3 \mathrm{~cm}$.

O pulmão direito dos quatis mediram em média 12,6cm de comprimento, desde seu ápice cranial até sua base caudal, concordando com Hare (1975), que afirma que o pulmão direito dos carnívoros são maiores que o pulmão esquerdo. Sua largura máxima (encontrada no lobo caudal) foi de $6,3 \mathrm{~cm}$ desde a sua borda medial até a sua borda costal. Apresentou-se dividido em quatro lobos (cranial, caudal, médio e acessório), onde três deles estavam divididos por fissuras (lobo cranial, caudal e médio) e o lobo acessório estava posicionado sobre o lobo caudal em sua vista ventral.

O lobo cranial direito mediu em média $5,6 \mathrm{~cm}$ de seu ápice cranial até a sua base na fissura interlobar cranial, base esta que se encontrou recoberta em parte pelo lobo médio. Sua largura foi em média $4,5 \mathrm{~cm}$ e sua maior espessura $(1 \mathrm{~cm})$ foi encontrada na região médiomedial do lobo. 
FIGURA 7: Fotografia e Fotomicrografias do pulmão e dos brônquios do quati (Nasua nasua). Em A o pulmão em vista ventral, lobos: cranial esquerdo (a); caudal esquerdo (b), caudal direito (c), medial (d), cranial direito (e) e acessório (f); carina traqueal (Ct); em B bronquíolo (seta), vasos sanguíneos (V), artéria (Ar), alvéolos (A); C brônquio primário notar epitélio pseudoestratificado ciliado (seta cheia) e ácino seroso (seta fina); em D brônquio secundário o epitélio pseudoestratificado ciliado (seta cheia) e cartilagem hialina com grupos isógenos de condrócitos (seta fina); E observar brônquio terciário o epitélio pseudoestratificado ciliado (seta cheia) e músculo liso (M); em F notar os sacos alveolares (A) e ducto alveolar (seta); G destaque da imagem notar pneumócito tipo I (seta fina), pneumócito tipo II (seta grossa) nos alvéolos pulmonares e macrófagos (M).H.E Barra: $20 \mu \mathrm{m}$ e $200 \mu \mathrm{m}$.
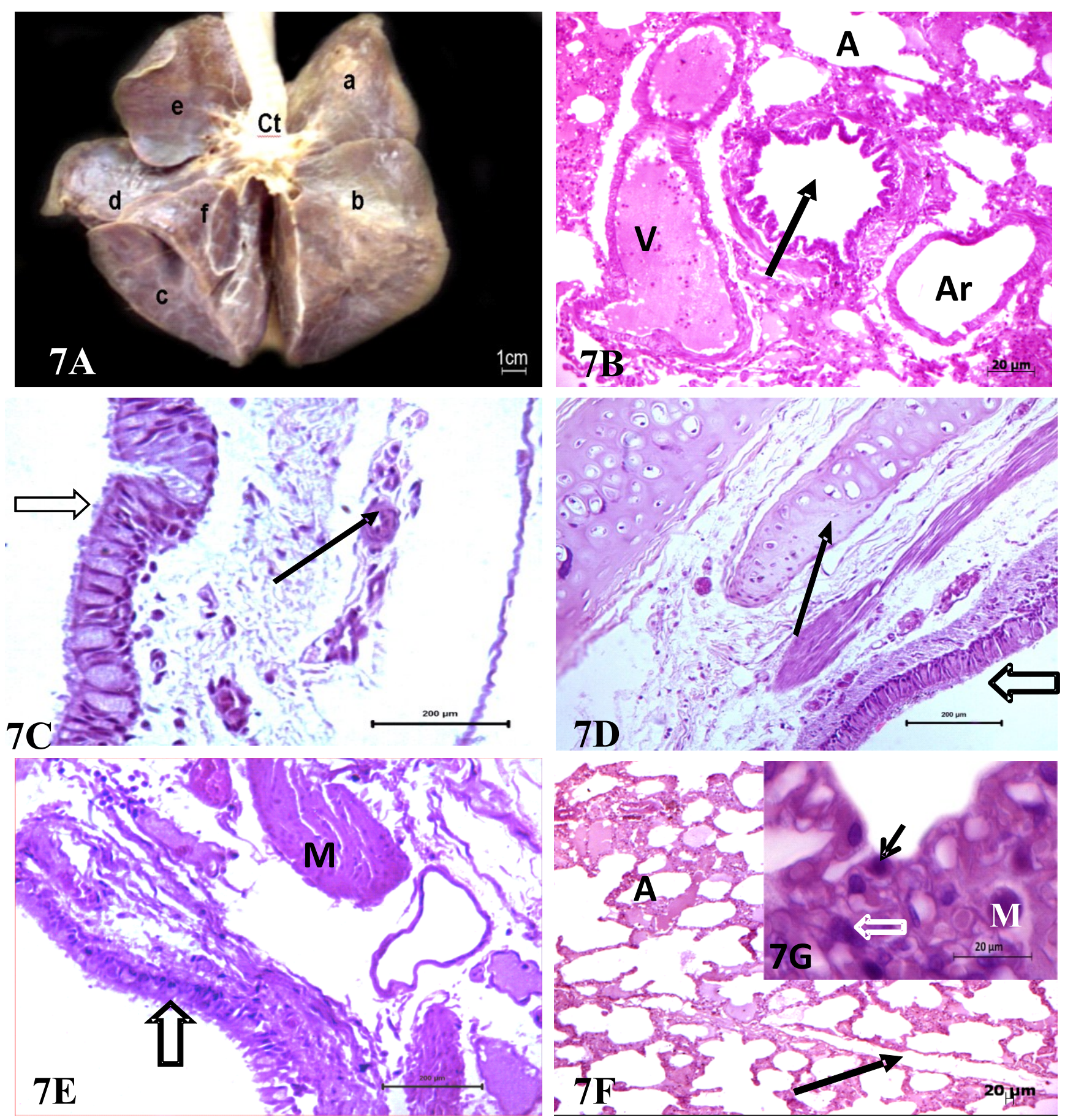
O lobo médio apresentou $3 \mathrm{~cm}$ de comprimento, desde seu ápice na fissura interlobar cranial (que sobrepõe em parte a base caudal do lobo cranial) até sua base na fissura interlobar caudal. Sua largura máxima foi de $5,5 \mathrm{~cm}$ de sua borda medial até sua borda costal e, sua maior espessura $(2 \mathrm{~cm})$ foi encontrada próxima de sua base.

O lobo caudal em média apresentou $6 \mathrm{~cm}$ de comprimento máximo, de seu ápice cranial na fissura interlobar cranial até a sua borda caudal. Sua largura máxima foi de $5 \mathrm{~cm}$ em média (de sua borda medial à sua borda costal) e sua maior espessura $(1,7 \mathrm{~cm})$ foi encontrada na borda medial do lobo.

O lobo acessório mediu em média $3,2 \mathrm{~cm}$ de comprimento de seu ápice cranial à sua base caudal, e $3,3 \mathrm{~cm}$, de borda medial até sua borda costal e sua maior espessura foi de $1 \mathrm{~cm}$ próximo de sua borda lateral.

Para Canals et al. (1998), em sua pesquisa com mamíferos, a árvore brônquica é composta por vias aéreas localizadas fora dos pulmões (brônquios primários extrapulmonares) e dentro dos pulmões são os brônquios secundários e terciários. Os brônquios extrapulmonares ou extrapulmonares primários nascem da bifurcação com a traqueia na carina traqueal, sendo semelhante no quati.

Os brônquios primários, secundários e terciários do quati, conforme se ramificam, decrescem progressivamente em diâmetro e tamanho, por esse motivo foram observadas várias mudanças que incluem a cartilagem hialina que diminui em quantidade e espessura, a quantidade de células caliciformes do epitélio diminui também em grande quantidade, concordando com Canals et al. (2002) em ratos. Nos brônquios primários, secundários e terciários o epitélio encontrado foi do tipo pseudoestratificado ciliado, foram encontrados ácinos serosos, cartilagem hialina com grupos isógenos de condrócitos e músculo liso (Figura 7C, D e E).

Igualmente citado por Gartner e Hiatt (1999), nos humanos, e por Toquetti et al. (2009), em bovinos, foram encontrados no quati os bronquíolos, vasos sanguíneos, artérias, sacos alveolares e ductos alveolares (Figura 7B e F). Os alvéolos dos pulmões estavam revestidos por dois tipos celulares, pneumócitos tipo I e II, o pneumócito tipo I tem a região do núcleo mais larga e abriga à maioria das organelas celulares, esse tipo celular ocupa mais de $95 \%$ da superfície da área de cada alvéolo e esta intimamente associada ao tecido conjuntivo subjacente que é ricamente vascularizado (Figura 7G). O pneumócito tipo II é morfologicamente diferente da célula tipo I, são células cúbicas que formam zona de oclusão com os pneumócitos do tipo I. Sua superfície projeta-se para dentro do lúmen do alvéolo, possuem núcleo situado centralmente. Nos alvéolos também foram encontrados macrófagos (Figura 7G).

Concluímos que o sistema respiratório do quati se assemelha aos descritos na literatura para carnívoros domésticos, diferenciando o nariz pelo formato pontiagudo e voltado para cima; conchas nasais dorsais e ventrais e a traqueia pelos números de anéis traqueais sendo 34 no quati e 42 a 46 no cão.

\section{Agradecimentos}

À UNIFEOB pelo incentivo à produção científica e ao apoio financeiro da FAPESP por permitir a dedicação à pesquisa em período integral do autor principal.

\section{Referências}

BEHMER, O. A.; TOLOSA, E. M. C.; NETO, A. G. F. Manual de técnicas para histologia normal e patológica. São Paulo: Edart, 1976. 241 p.

BEISIEGEL, B. M. Notes on the coati, Nasua nasua (Carnívora: Procyonidae) in na Atlantic Forest area. Brazilian Journal of Biology, São Carlos, v. 61, n. 4, p. 689-692, 2001.

BORGES, E. M.; OLIVEIRA. F. S.; MACHADO. M. R. F.; RIBEIRO. A. A. C. M.; SILVA SOBRINHO, A. G. Segmentação anatomocirurgica arterial dos pulmões de ovinos da raça ideal (OvisAires, Linneu,1758) Brazilian Journal of Veterinary Research and Animal Science, São Paulo, v. 39, n. 6, p. 288-293, 2002.

CANALS, M.; ATALA, C.; OLIVARES, R.; NOVOA, F. F.; ROSENMANN, M. La asimetria y el Grado de Optimización del Arbol Bronquial en Rattus norvegicus y Orictolagus cuniculus. Revista Chilena de Historia Natural, Santiago, v. 75, n. 2, p. 271 282, 2002.

CANALS, M.; OLIVARES, R.; LABRA, F.; CAPUTO, L.; RIVERA, A.; NOVOA, F. F. Caractezacion de la geometria fractal del arbol bronquial em mamíferos. Revista Chilena de Anatomia, Temuco, v. 16, n. 2, p. 237-244, 1998. 
CARRIJO, K. F. Pneumonia enzoótica em suínos de abate: relação entre lesões pulmonares e renais. 2007. 114 f. Dissertação (Mestrado em Ciências) - Universidade Federal Fluminense, Rio de Janeiro. 2007.

COPPER, G.; SCHILLER, A. L. Anatomy of the guinea pig. Massachussetts: Harvard University Press, 1975. p. 371-380.

CITRÂNGUlO, M.; RIBEIRO, A. A. C. M.; MORAES, P. T. B.; MACHADO, M. R. F. Lobação e vascularização arterial do pulmão da capivara (Hydrochaeris hydrochaeris). Arquivo de Ciências Veterinárias e Zoologia da UNIPAR, Umuarama, v. 4, n. 2, p. 119-127, 2001.

CUNNINGHAN, J. G. Tratado de fisiologia veterinária. 3. ed. Rio de Janeiro: Guanabara Koogan, 2004. 579 p.

DYCE, K. M.; SACK, W. O.;WENSING, C. J. G. Tratado de Anatomia Veterinária. 3. ed. Rio de Janeiro: Guanabara Koogan, 2004. 813 p.

EVANS, H. E. Anatomy of the dog. Philadelphia: W. B. Saunders, 1993. p. 487-492.

GARTNER, L. P.; HIATT, J. L. Tratado de histologia. Rio de Janeiro: Guanabara Koogan, 1999. 414 p.

GREENE, E. C. The anatomy of the rat. New York: Hafner Publishing, 1995. $370 \mathrm{p}$.

HARE, W. C. D. Sistema respiratório do carnívoro. In: GETTY, R. (Ed.). Anatomia dos Animais Domésticos. v. 2. 5. ed. Rio de Janeiro: Guanabara Koogan, 1975. p. 1465-1479.

INTERNATIONAL COMITEE ON VETERINARY GROSS ANATOMICAL NOMENCLATURE. Nomina histological veterinaria. 2. ed. Columbia: Editorial Committee Hannover, 2005. $166 \mathrm{p}$.

JUNQUEIRA, L. C.; CARNEIRO, J. Histologia básica. 9. ed. Rio de Janeiro: Guanabara Koogan, 1999. 488 p.

KÖNIG, H. E.; LIEBICH, H.G. Anatomia dos animais domésticos. In: GETTY, R. (Ed.). Anatomia dos animais domésticos. v. 2. Rio de Janeiro: Guanabara Koogan, 2004. p. 81-156.

MILLAS, I.; LIQUIDATO, B. M.; DOLCI, J. E. L.; FREGNANI, J. H. T. G.; MACÉA, J. R. Análise histológica do padrão de distribuição glandular em conchas nasais inferiores normais. Brazilian Journal of Otorhinolaryngology, São Paulo, v. 75, n. 4, p. 507-510, 2009.

NAKAKUKI, S. The bronchial tree, lobular division and blood vessels of the woodchuck (Marmota monax) lung. Kaibogaku Zasshi, Tokyo, v. 69, n. 1, p. 14-21, 1994.

OLIVEIRA, F. S.; MACHADO, M. R. F.; MIGLINO, M. A.; RIBEIRO, A. A. C. M. Contribution to the anatomic study of the lungs of buffaloes (Bubalus bubalis-Linnaeus, 1758). Brazilian Journal of Morphological Sciences, São Paulo, v. 16, n. 1, p. 6973, 1999.

ORR, R. T. Biologia dos vertebrados. 5. ed. São Paulo: Roca, 1986. 508 p.
PENNO, A. K.; CARVALHO, M. A. M.; ASSIS-NETTO, A. C.; AZEVEDO, L. M.; MELLO, G. W. S. Lobação, ramificação brônquica e distribuição arterial no pulmão da cutia (Dasyproeta sp., Mammalia - Rodentia). Brazilian Journal of Veterinary Research and Animal Science, São Paulo, v. 42, n. 5, p. 331-336, 2005.

PEREIRA. M. C. Efeito da mitomicina C tópica sobre os depósitos de colágeno total na submucosa das pregas vocais íntegras de suínos. 2006. 62 f. Dissertação (Mestrado em Clinica Cirúrgica) - Universidade Federal do Paraná, Curitiba. 2006.

REDHER, A. M. A. Lobação e distribuição bronquial e arterial do pulmão de paca (Agouti paca, Linneus, 1776). 2005. $50 \mathrm{f}$. Dissertação (Mestrado Ciências) - Universidade de São Paulo, São Paulo. 2005.

REGINATO, A. L.; MELO, A. P. F. Segmentação anátomo-cirúrgica em baços de queixada (Tayassu pecari - Link, 1975). Brazilian Journal of Veterinary Research and Animal Science. v.41, n.4, p. 281-285, 2004

RESENDE, H. R.A.;ALONSO, L. S.; BIRCK,A. J.; FILADELPHO, A. L.; PERES, J. A.; BALIELO, F. N.; SILVA-JÚNIOR, C. A. Aspectos histológicos da traqueia do ratão do banhado (Myocastor coypus Molina, 1782). Revista Cientifica Eletrônica de Medicina Veterinária, Garça, v. 4, n. 8, 2007. Versão eletrônica.

RUSSEL, J. K. Timing of reproduction by coatis (Nasua narica) in relation to fluctuations in food resources. In: LEIGH JR., E. G.; RAND, A. S.; WINDSOR, D. M. (Ed.). The ecology of a tropical forest. 2. ed. Washington: Smithsonian Institution Press, 1996. p. 413-431.

SANTOS, T. C.; TRUJILlO, U. A. G; ALBERTTO, M. L. V.; PEREIRA, C. H.; FERRARI, C. C.; MENCONI, A.; BOMBONATTO, P. P. Aspetos morfológicos e morfométricos da traquéia em gansos domésticos. Biotemas, Florianópolis, v. 20, n. 2, p. 91- 96, 2008.

TEIXEIRA, R. H. F.; AMBRÓSIO, S. R. Carnívora-Proyonidae. In: CUBAS, Z. S.; SILVA, J. C. R.; DIAS, J. C. (Ed.). Tratado de animais selvagens. São Paulo: Roca, 2007. p. 571-573.

TRINDADE, L. B.; ANDRADE, E. A. E.; MELO, A. P. F. Segmentação do pulmão de fetos de bovinos azebuados. Brazilian Journal of Veterinary Research and Animal Science, São Paulo, v. 40, n. 2., p. 95-99, 2003.

TOLOSA, E. M. C.; RODRIGUES, C. J.; BEHMER, O. A.; FREITAS NETO, A. G. Manual de técnicas para histologia normal e patológica. 2. ed. Barueri: Manole, 2003. 331 p.

TOQUETTI, R. C.; GUERRA, R. R.; AMBRÓSIO, C. E.; SANTOS, J. M.; FAVARON, P. E.; FRANCIOLI, A. L. R.; ALBERTO, M. V.; MEIRELLES, F. V.; MIGLINO, M. A. Morfologia e funcionalidade do Pneumócito tipo II e sua relação e variação com a idade gestacional em bovinos. Ciência Rural, Santa Maria, v. 39, n. 8, p. 2470-2477, 2009.

ZELLER, U. Mammalian reproduction: origin and evolutionary transformations. Zoologischer Anzeiger, Berlin, v. 6, n. 2, p. 117$130,1999$. 